Works of the Faculty of Forestry

University of Sarajevo

No. 2, 2018 (65-77)

UDK 639.1.05/.08

\title{
APPLICATION OF NEW TECHNIQUES AND TECHNOLOGIES IN HUNTING
}

\section{Primjena novih tehnika i tehnologija u lovstvu}

Marijan Grubešić ${ }^{1}$, Saša Kunovac ${ }^{2}$, Živko Rapaićn ${ }^{3}$, Mustafa Bašić ${ }^{4}$, Kristijan Tomljanović ${ }^{1}$

\section{Abstract}

The development and application of new techniques and technologies in hunting management, scientific research and professional work in the hunting domain is a continuous process. Numerous technical achievements are often applied and targeted operationally in hunting and the exploration of game and its habitat.

When analysing the past period, and the latest technical and technological achievements in hunting, one can point out several very significant examples of the application of new techniques and technologies in hunting, such as:

- The development and application of live game capture methods, with particular emphasis on catching chamois in Bosnia and Herzegovina;

- Chemical immobilization (tranquilizing) in research or transport of live game;

- The use of sensory cameras (photo traps) for game tracking and surveillance of the hunting grounds (ordinary sensory cameras, IC cameras);

- Telemetric tracking of game, from large carnivores up to small game species with classic devices and GPS devices;

- Measuring microclimate elements with precision instruments on selected micro locations in wildlife habitats;

- Use of sensory sound repellents for game-avoidance (ultra - and infrared devices);

- Use of lightweight unmanned aerial vehicles for wildlife habitat analysis using a classical camera;

- Use of lightweight Unmanned aerial vehicles to determine the numerous status and game structure using a thermal imaging camera;

All the above-mentioned techniques and technologies have given, and make, a significant contribution to the scientific research work in the field of hunting and to a large extent in the daily operational application of hunting management, monitoring and protection of game and animal species.

Key words: hunting, research, technical means, technology, hunting management

\footnotetext{
${ }^{1}$ Faculty of Forestry of University in Zagreb, Department for Forest Protection and Hunting Management, Svetošimunska 25, HR - 10000 Zagreb

${ }^{2}$ Faculty of Forestry, University of Sarajevo, Zagrebačka 20, 71000 Sarajevo, Bosnia and Herzegovina

${ }^{3}$ Grbavička 2, 71000 Sarajevo Bosnia and Herzegovina

${ }^{4}$ Cantonal Forestry Office, Stanična 43,72270 Travnik, Bosnia and -Herzegovina
} 


\section{INTRODUCTION - Uvod}

Development and application of new techniques and technologies in hunting, scientific and professional work in the field of game management is a continuous process. Numerous technical achievements often are especially developed for application in game management.

From ancient times, humans developed various techniques prior to game hunt. Later on, those techniques become more useful in scientific work considering the game, its habitats, and behavior or integral activities in people-habitat-game relations.

As well as the first activity of humans was ,hunters-gatherers“, some think that the development of hunting techniques and technologies had a significant impact on the social and intellectual development of humans themself. Hunting was a well-known practice for the improvement of different skills, particularly sport or military ones (Blüchel, 2011). some methods but also means for game hunt are still in use today, like nets, traps, snares, hunting with birds of prey, etc. The latest technical accessories are mainly used for scientific work in game management, like sensory cameras, game telemetry, chemical immobilization, sound repellents, portable meteorological instruments or lightweight unmanned aircraft.

\section{AIM OF WORK - Cilj rada}

Aim of this review is to present different techniques and technologies, which are in use in game management or researches considering game species and their habitats. Some of them can be widely in use ( like portable meteorological instruments), and some are specialized just for game capturing and translocation, monitoring or game inventory. However, before the appliance of new devices, techniques, and technologies, it is necessary to test their efficiency and reliability. According to this, in this paper, we presented some of the mentioned techniques and technologies as well as results that are achieved with their use.

\section{METHODS - Metode rada}

Live game capturing is known for more than 2000 years (Blüchel, 2011), but methods and techniques are still in progress. In the past century, chamois live capturing was conducted in Bosnia-Herzegovina to repopulate habitats in neighboring countries (Serbia, Croatia) as well as in $\mathrm{BiH}$, or to introduce this species in foreign countries (New Zealand, Argentina). This extraordinary project, was realized in very hard terrain conditions and with limited technical and technological resources. Nets were used for chamois capturing, after detail and accurate choice of localities, preparations, nets mounting, education of bitters, co-workers for capturing and further chamois translocation.

Utilization of sensory cameras (photo traps) for game monitoring and surveillance of hunting ground, is an obligatory in practice or research, even for solitary hunters nowadays. There was a need for testing functionality of sensory cameras, their 
efficiency as well as their disadvantages concerning other means of game monitoring and surveillance of hunting grounds. Those tests were performed concerning the distance of sensor reaction, comparison between cameras with flash or infrared cameras, and the possibility of determination of game age and sex.

Game telemetry with the usage of GPS collars in the Balkan region has its first appliance on large carnivores species. Besides this, there was researches at grey partridge. The telemetry of grey partridges (bred in pheasantries) was conducted to determine their migrations, survival and habitat preferences after introduction in nature.

Portable meteorological instruments were used in numerous locations in Bosnia-Herzegovina, for testing and comparing climate conditions in habitats of rock partridge with official data at State meteorological stations, located mainly in cities or at a significant distance from rock partridge habitats.

Sensory infra and ultrasonic devices were tested to determine the efficiency of these devices in game damages prevention. Testing was conducted at several locations together with the use of sensory cameras for monitoring game reaction after activation of ultra and infrasonic devices.

Unmanned aerial vehicles (UAV), commonly known as a drone, have widespread usage in game inventory in combination with term vision cameras or habitat structure researches in a combination of ordinary cameras. Drones can provide very detailed and reliable data about the current situation in game habitats as well as population condition. Testing of drones efficiency was realized in Croatia for determining exact surface structure in hunting grounds and for game inventory with total counting at some localities and transect method at large surfaces.

\section{RESULTS - Rezultati}

Live capturing of chamois in Bosnia-Herzegovina was conducted in mountains Prenj and Čvrsnica. Well-chosen localities for capturing (mainly paths of usual daily migrations), carefully mounted nets in three rows, educated personnel for chasing, capturing, putting in boxes and translocation, resulted in 434 captured and successfully translocated animals. Captured chamois were released at two locations in Croatia, two in Serbia and ten localities in Bosnia-Herzegovina (from which this species were exterminated). The icing on the cake in this project was capturing 37 chamois which were successfully translocated in Argentina and New Zealand. 
Loses on chamois in this project were nearly $10 \%$.
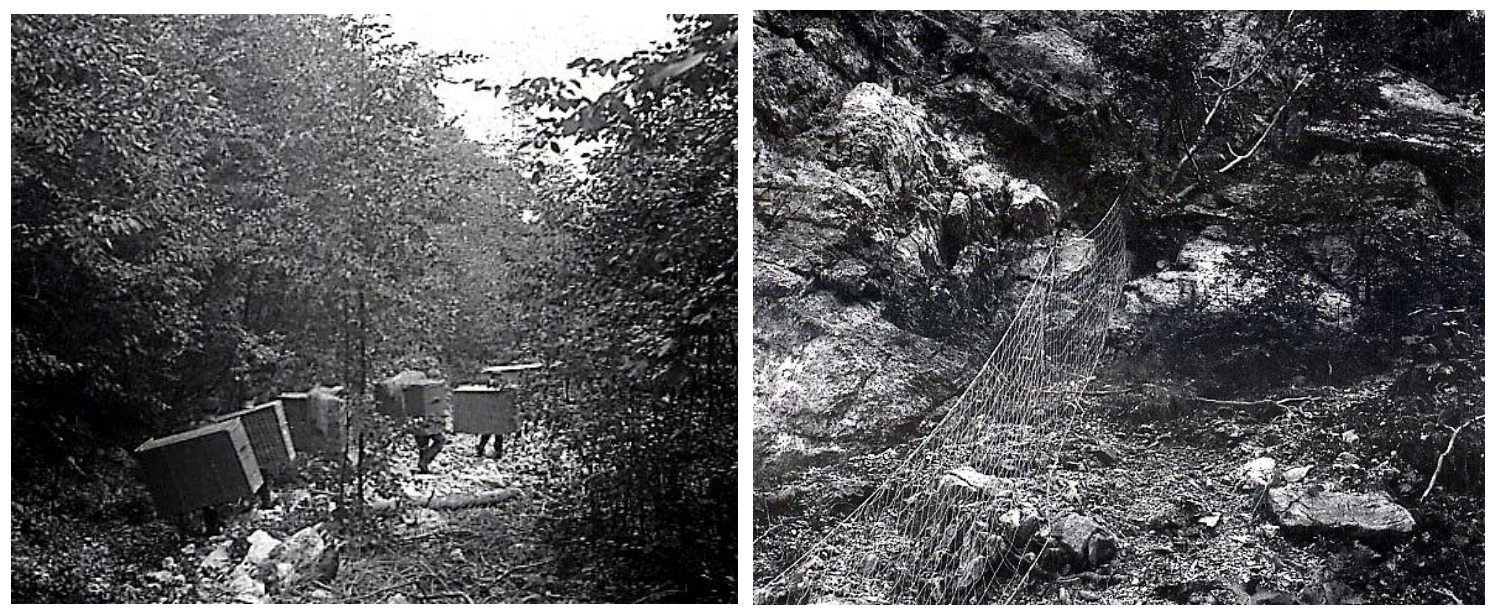

Figures 1 and 2. Mounted nets and transport of captured chamois in wood baskets

\section{Slike 1 i 2. Postavljene mreže i transport uhvaćenih divokoza u korpama od pruća}

Intensive game management, especially increasing demands for introduction, reintroduction or repopulation of game populations caused appropriate development of methods of live capturing. Nowadays, beside nets, we use various traps, snares, cirruses, etc. After capturing, it's common to use systems for immobilizations of game for further treatment, measuring or translocation. With these immobilization systems, we put animals into a position in which it can endanger either personnel or itself.

Another way for capturing, treatment or translocation is chemical immobilization, which is performed with giving sedatives to game animals. Today, mainly Zoletil 50 or 100 in combination with $10 \%$ xylazine is in use.

The appliance of sensory cameras in game inventory, age, and sex determination, occurring new game species, etc, is the necessary equipment of every game manager. Instead of hunters-observers, cameras doing this job continuously in certain parts of hunting grounds on a daily/monthly/yearly basis. Today we have numerous manufacturers and types of sensory cameras, but we divide them into two basic types: cameras with flash and infrared cameras.

Cameras with flash provide better photos, especially during the night or in conditions of reduced visibility, but often flash can scare game animals. Infrared cameras are practically indistinguishable, but with less quality photos during the night. The key element in the camera is its sensor. Testing just this element, we concluded that the optimal distance of animals is 10-15 meters(exceptionally up to 20 $\mathrm{m})$ this is a ,weak" point at all types of cameras. This disadvantage can be partly reduced with camera programming to make a photo or clip at certain time intervals. 
Marijan Grubešić, Saša Kunovac, Živko Rapaić, Mustafa Bašić, Kristijan Tomljanović

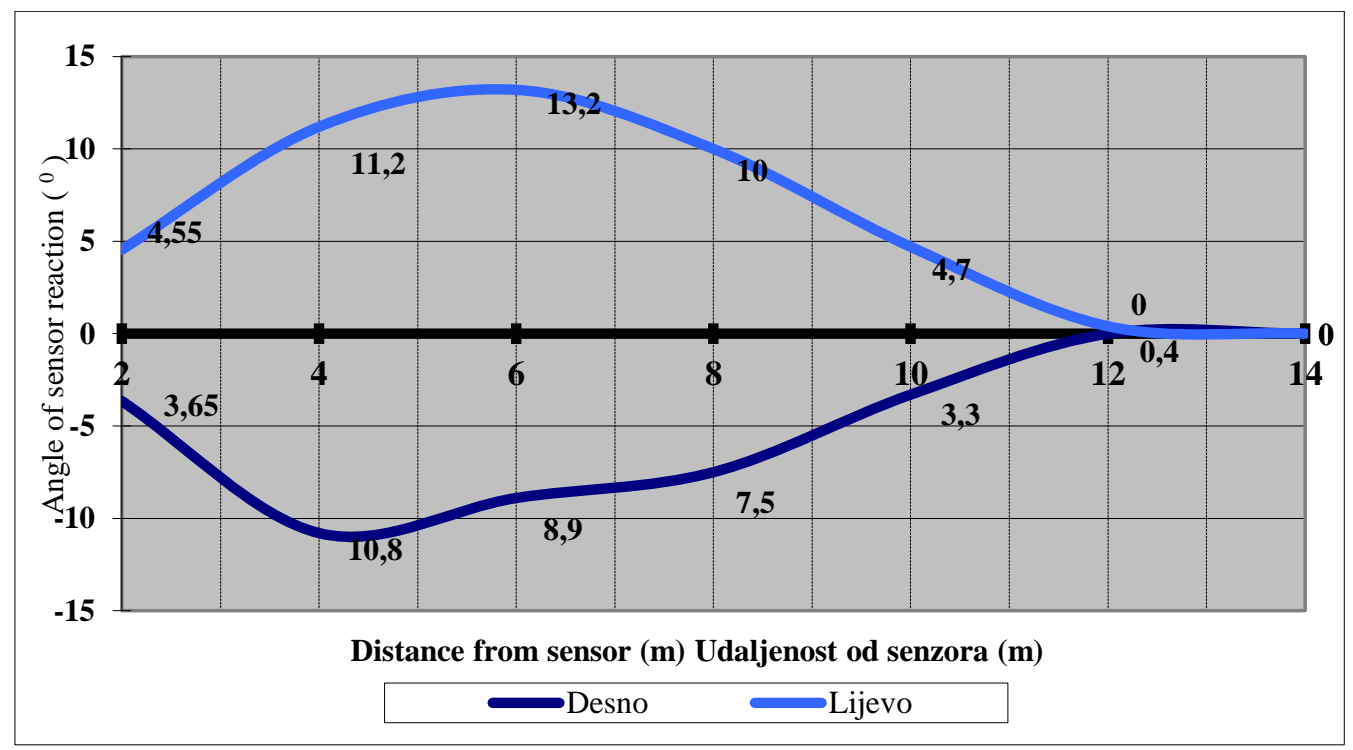

Graphic 1. Results of sensor testing according distance of object

Grafikon 1. Rezultati testa senzora u odnosu na udaljenost objekta
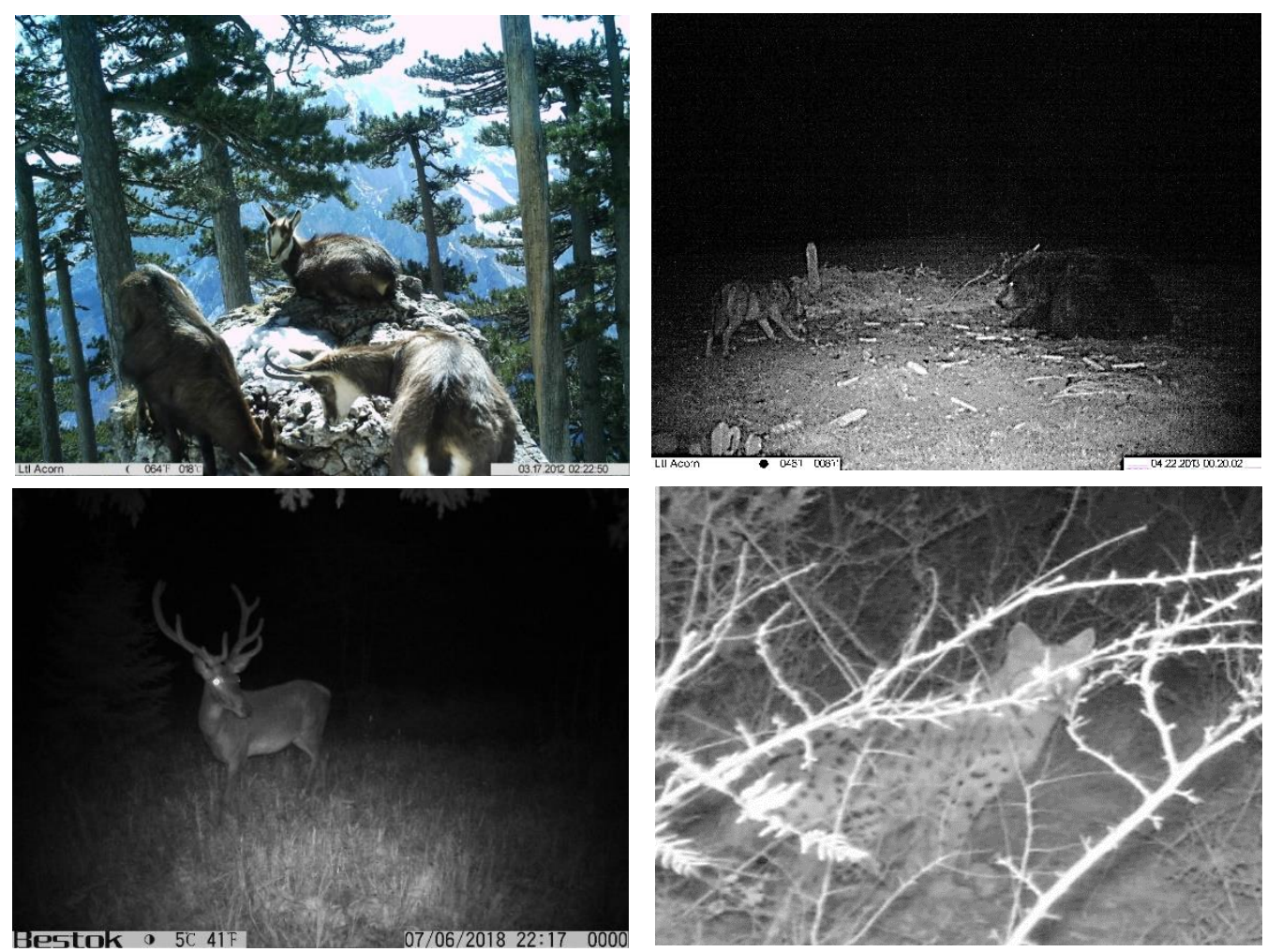
Figures 3-6. Determination of age and sex, competition between species and detecting rare species using sensory cameras in $\mathrm{BiH}$.

Slike 3-6. Utvrđivanje starosti i pola, kompeticije između vrsta i opažanje rijetkih vrsta pomoću nadzornih kamera u BiH.

Game telemetry has been conducted for more than 30 years. From appliance of classic collars with a transmitter, antenna, and receiver till nowadays when we use GPS collars and satellite tracking of game animals.

Research at grey partridge in Croatia has been done with „classical“ telemetry. With this research, we determined the survival rate of released partridges as well as home range after releasing. Results are presented in table 1 and graphic 2:

Table 1. Comparison of the length of survival of released birds at three sites

Tabela 1: Usporedba duljine preživljavanja ispuštenih jedinki na tri lokaliteta

\begin{tabular}{|l|c|c|c|}
\hline Lokaliteti ispuštanja / Compared locality`s & t-value & df & p \\
\hline $\begin{array}{l}\text { Lokalitet 1 - ljeto vs. Lokalitet 2 - jesen } \\
\text { Locality 1 - sumer vs. Locality 2 - autumn }\end{array}$ & 3,75005 & 7 & 0,007168 \\
\hline $\begin{array}{l}\text { Lokalitet 1 - ljeto vs. Lokalitet 2 - proljeće } \\
\text { /Locality 1 - sumer vs. Locality 2 - spring }\end{array}$ & 5,82094 & 11 & 0,000116 \\
\hline $\begin{array}{l}\text { Lokalitet 2 - jesen vs. Locality 2 - proljeće } \\
\text { Locality 2 - autumn vs. Localit 2 - spring }\end{array}$ & 1,98959 & 10 & 0,074672 \\
\hline
\end{tabular}

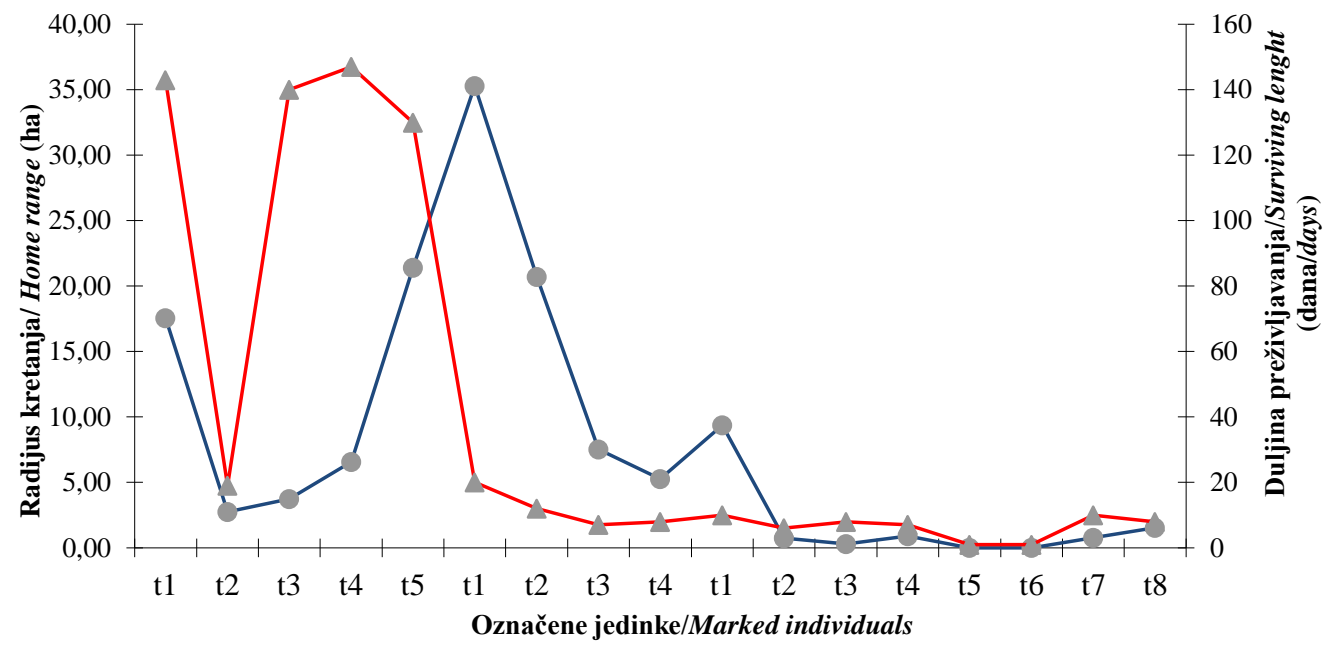

— Radijus kretanja/Home range _ _ _ Duljina preživljavanja/Surviving

Graphic 2: Home range and survival length of released partridges

Grafikon 2: Radijus kretanja i dužina preživljavanja ispuštenih jarebica 
From table and graphic, we can see that the longest survival rate has partridges that have been released in summer (survived until autumn crops removal), and the shortest partridges released in spring when predators are the most active cause of raising its youngsters.

The home range was largest in autumn and smallest in spring, which can be related to available food and cover, respectively to crop removal in autumn and forcing partridges to change locality of living.

Measuring of micro-climate conditions in rock partridge habitats with portable meteorological stations has been done in mountains of central Bosnia-Herzegovina. Results showed significant differences between obtained data and data from State meteorological stations, which are mainly located in cities or large settlements. We comared data from State meteorological station located in Bugojno, with data collected at different locations (foothill, middle and top of mountains) at field. With changing of altitude, differences are more significant as shown at the following figures:

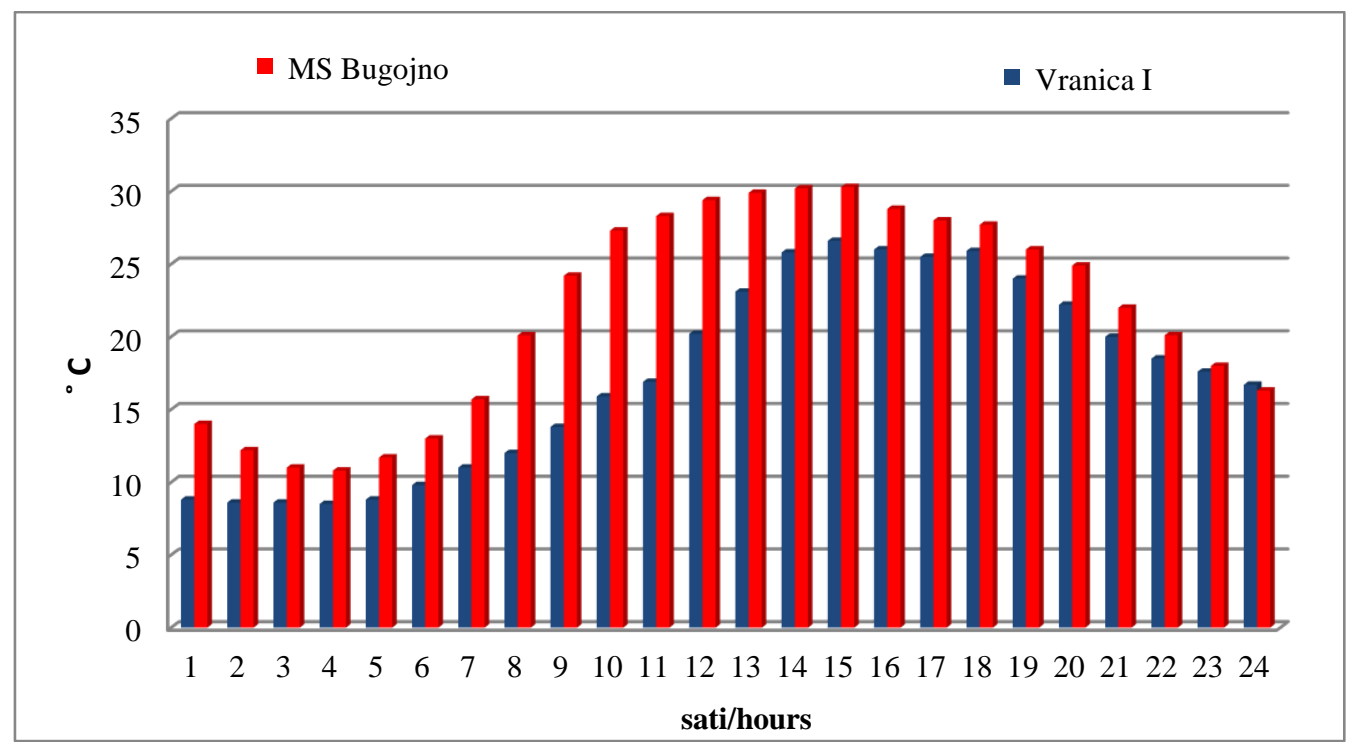

Graphic 3: Temperature differences in foothill of Vranica I locality - $891 \mathrm{~m}$. a.s.1; Grafikon 3: Mjerenje temperaturnih razlika u podnožju lokaliteta Vranica I - 891 m.n.v; 


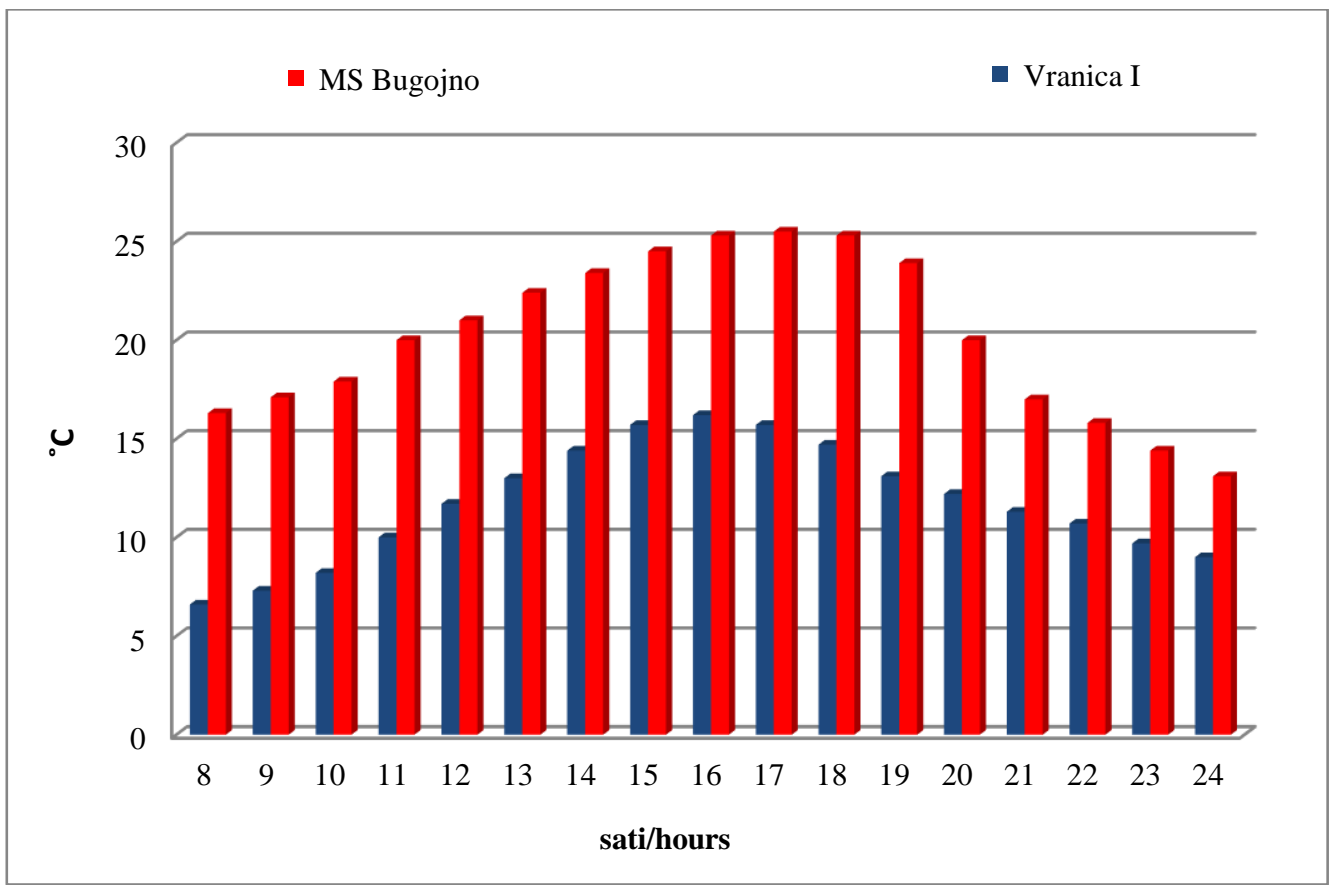

Graphic 4: Temperature differences in middle of Vranica I locality - $1382 \mathrm{~m}$. a.s.1;

Grafikon 4: Mjerenje temperaturnih razlika u sredini lokaliteta Vranica I - 1382 m.n.v;

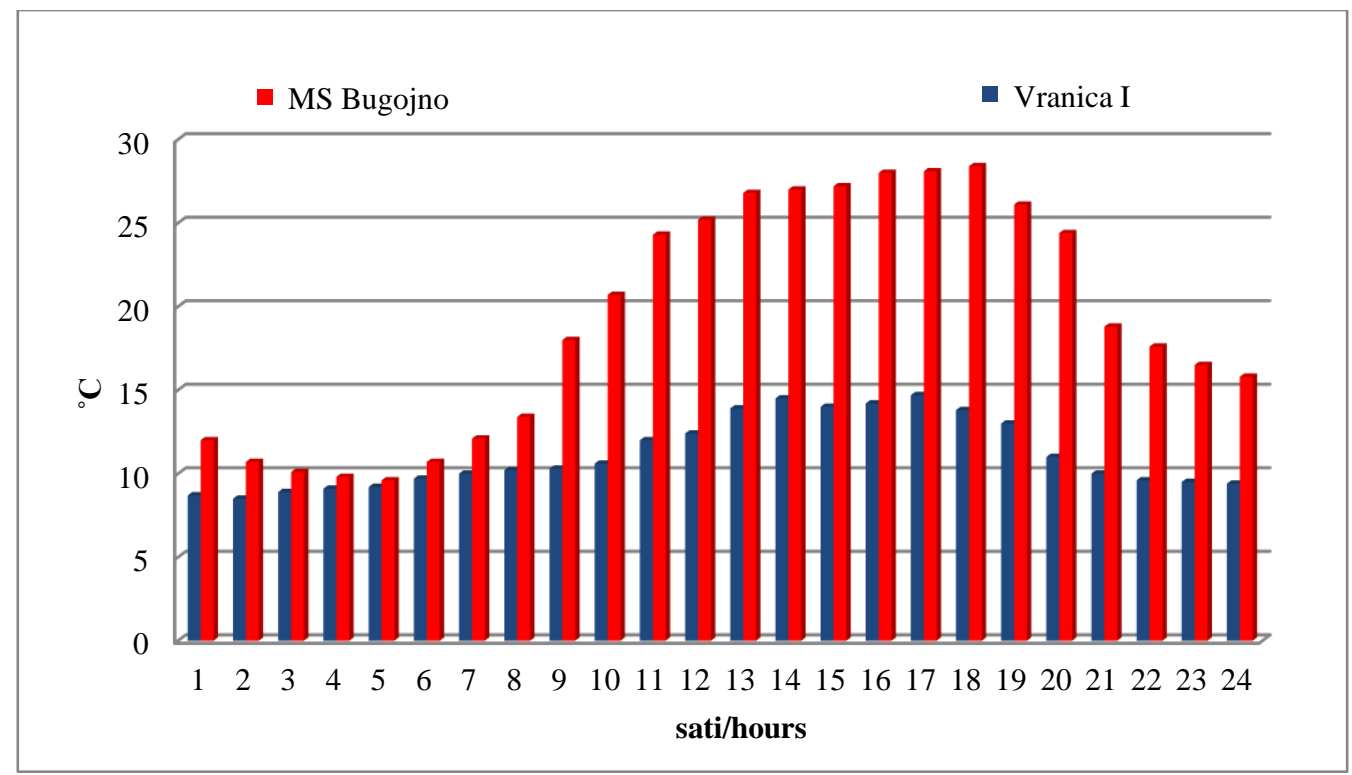

Graphic 5: Temperature differences at top of Vranica I locality- 1688 m. a.s.1;

Grafikon 5: Mjerenje temperaturnih razlika na vrhu lokaliteta Vranica I- 1688 m.n.v; 
Testing of sensory infra and ultrasonic devices for preventing game (wild boars and red deer) damages at crops, orchards, etc, were conducted at several locations. Research has been done in combination with sensory cameras to determine wild boar and deer reaction.

Based on the result of research it has been determined that when preventing crop damage, game animals (particularly wild boars) ignore infra and ultrasonic „barrier“. So these devices are not efficient in crop damage prevention. Researches conducted in Slovenia showed sufficient efficiency in preventing game animals to cross traffic roads.

\section{Unmanned Aerial Vehicles}

Those devices have different names in literature as UAS (Unmanned Aircraft Systems), or rarely as RPV (Remotely Piloted Vehicles). Common name „drone "comes from the US army, which first uses it as UCAV (Unmanned combat aerial vehicle), combat drone or just drone. Conducted researches with drones had two intentions:

- Habitat analysis

- Game inventory

The first appliance considers determining real conditions of surfaces (forests, meadows, pastures, orchards, etc) in hunting ground for the purpose of accurate assessment of carrying capacity for certain game species. We used high-resolution cameras, mounted on drones and scanned terrain with consecutive photos. Most of the drones have GPS, so every photo taken can be put into space. With the use of specialized programs, we can create a 3D model of whole hunting ground. İ this way, we have a reliable basis for determining carrying capacity. Within the last years, we can use Google Earth. Although Google Earth photos are quite new, sometimes it takes only a year or two that some meadow or pasture become overran with dense vegetation. So, the technology of drones' appliance provides a much better solution considering the price of these operations (Nosek, 2017; Tomljanović, 2018).

Also, we can use drones in the monitoring of some parameters in game populations. İn winter 2017, we conducted a game inventory in densely forested areas in Croatia. The method of a total count of certain game species is appropriate for smaller plots with known size. Transect method, where we count animals at previously determined directions is eligible for larger plots as a sample method. İn testing we noticed that contrast between animals spotted and its surroundings is higher at lower temperatures. The most convenient time for this kind of game inventory (term vision camera mounted at drone) is early morning with frost and clouds. With the daily temperature rising contrast is lower, so detection (count) of game becomes more difficult. Opposite from this, lower temperatures have a significant influence on a drone's battery life, so several batteries are necessary for this kind of research. Obtained results point to large possibilities of drone appliance for the purpose of research but also practical game management. Within minutes, a drone can "cover" almost 100 ha, and detect all game animals in the area. With this, we replace quite a large number of engaged personnel (in regular counts) and reduce the possibility of mistakes (Tomljanović, 2018). 


\section{DISCUSSION - Diskusija}

New techniques and technologies, technical accessories, research equipment and devices are a constituent part of scientific work in hunting, but also in daily activities in game management. Some of the presented technologies or devices provide a great contribution to better knowledge about game species, its habitats and generate changes in game management guidelines. From appliance of the oldest methods of animal capture, which are in use for centuries (traps, nets, snares) to modern systems for animal capture, immobilization, treatment, and translocation.

Nowadays widespread in use, even at an individual level, sensory cameras, replace days and nights of observing certain micro-location on hunting grounds. Besides monitoring, count and determining age and sex, cameras also play an important role in hunting ground surveillance (e.g. poaching).

Game telemetry and constant monitoring of it, using this technology, reveal numerous secrets about game animals, providing necessary data about daily and season rhythm, migration or habitat preference.

Game damage problems, take the first place in the category of human-animal conflicts. Besides classic means of preventing damage as fences, repellents, supplemental feeding, etc, some ultra or infrasonic devices can be used too. Some experiments in preventing car collisions with animals in Slovenia provide positive results (Pokorny, 2006). But preventing crop damage with these devices needs more improvement and research.

The latest technical achievements in game and habitat research are the appliance of Unmanned Aerial Vehicles in combination with different sophisticated cameras. This technique is still in development, will be dominant and widespread in further years both in research and practice. In any case, the development and appliance of techniques and technologies in game management follow other trends and branches in the world.

\section{CONCLUSIONS - Zaključci}

At the end of this review we can conclude as follows:

- Latest techniques and technologies significantly improve our knowledge about game species;

- In the same time, they make most operations in practice much easier (e.g. game inventory, translocation, or surveillance), with costs reducing;

- Further improvement and development of techniques and technologies have to be supported by game managers and academic institutions in order to achieve sustainable game management; 


\section{ACKNOWLEDGEMENT}

This paper was presented at International Symposium "People-Forest-Science", October 10-12, 2018, Sarajevo, Bosnia and Herzegovina.

\section{REFERENCES - Literatura}

BAŠı́́, M. (2016): Populacija jarebıce kamenjarke (Alectoris graeca Meıssner.), na području Srednjobosanskog kantona, Magistarski rad, Šumarski fakultet, Univerziteta u Sarajevu, str. 1-117. Sarajevo.

GRUBEŠIĆ, M., TOMLJANOVIĆ, K.: (2009): Praćenje divljači automatskim digitalnim fotokamerama, Lovački vjesnik broj 12, str. 42-43. Zagreb.

GRUBEŠIĆ, M., UROŠEVIĆ, B., MIHALJEVIĆ, Z., TOMLJANOVIĆ, K. (2011): Uzgoj i selekcija jelena običnog (Cervus elaphus L) u ograđenom prostoru i mogućnost ispuštanja $\mathrm{u}$ otvorena lovišta u Hrvatskoj, 3 Slovenski posvet $\mathrm{z}$ mednarodno upravljanju z divjadi: jelenjad. Ed. Poličnik, H., Pokorny, B., ERICO d.o.o., str. 54-57., Velenje.

GRUBEŠIĆ, M., SELETKOVIĆ, A., POLJAK, Ž., ŠĆULAC, T., TOMLJANOVIĆ, K. (2017): Poznavanje promjena u strukturi površina u lovištu kao osnova za smjernice lovnoga gospodarenja, $52^{\text {nd }}$ Croatian and $12^{\text {th }}$ International Symposium on Agriculture, str. 421-426, Dubrovnik, Hrvatska.

HUBER, Đ., JAKŠIĆ, Z., FRKOVIĆ, A., ŠTAHAN, Ž., KUSAK, J., MUSIĆ, J., MAJNARIĆ., D., GRUBEŠIĆ, M., KULIĆ, B., SINDIČIĆ, M., MAJIĆ SKRBINŠEK, A. (2008): Plan gospodarenja smeđim medvjedom u Republici Hrvatskoj, Ministarstvo regionalnog razvoja, šumarstva i vodnoga gospodarstva, Uprava za lovstvo, Zagreb.

KUNOVAC, S. (2009): Uputstvo za prebrojavanje divljači Šumarski fakultet Univerziteta u Sarajevu i Federalno ministarstvo poljoprivrede, vodoprivrede i šumarstva, Sarajevo.

KUNOVAC, S., RAPAIĆ, Ž., POPOVIĆ, Z., SALKIĆ, A., GRUBEŠić, M., KRASIĆ, P., BAČiĆ, M., MAUNAGA, Z. (2010): Korištenje lovišta Atlantik bb d.o.o, SarajevoBanja Luka - Priručnik.

KUNOVAC, S., BAŠIĆ, M., GRUBEŠIĆ, M.,TOMLJANOVIĆ, K. (2012): Characteristics of Rock partridge (Alectoris graeca Meisner) Habitat in Mountains of BosniaHerzegovina. Modern aspects of sustainable management of game population. International Symposium on Hunting, Proceedings, Zemun-Belgrade, 122-126.

NOSEK, H. (2017): Upotreba bespilotnih letjelica u lovnom gospodarenju, Diplomski rad, Šumarski Fakultet, Sveučilišta u Zagrebu, str 1-60. Zagreb.

POKORNY, B. (2006): Roe deer vehicle collisions in Slovenia: Situation, mitigation strategy and countermeasures. Veterinarski arhiv 76 (Suppl), str 177-187., Zagreb. 
RAPAIĆ, Ž., KUNOVAC, S., SOLDO, V. (2008): Ustanovljenje staništa divokozje divljači u BiH i prijedlog za revitalizaciju populacije. Federalno ministarstvo poljoprivrede, vodoprivrede i šumarstva, str. 1-128. Sarajevo.

TOMLJANOVIĆ, K., GRUBEŠIĆ, M., KRAPINEC, K. (2010): Testiranje primjenjivosti digitalnih senzorskih kamera za praćenje divljači i ostalih životinjskih vrsta, Šumarski list, broj 5-6, str. 287-292. Zagreb.

TOMLJANOVIĆ, K., GRUBEŠIĆ, M. (2015): Gospodarenje sa trčkom (Perdix perdix) u okolici Zagreba, Uzgoj divljači i zaštita biološke raznolikosti; Ed. Florijančić, T., Ozimec, S., str 13. Vinkovci.

TOMLJANOVIĆ, K., GRUBEŠIĆ, M., KONJEVIĆ, D., TOMAŠIĆ, Z. (2013): Uspjeh ispuštanja i podivljavanja trčke (Perdix perdix L.) iz umjetnog uzgoja u lovištima središnje Hrvatske, Šumarski list, broj 3-4, str 185-190. Zagreb.

TOMLJANOVIĆ, K.(2018): Mogućnosti primjene lakih bespilotnih letjelica u lovnom gospodarenju, Lovački vjesnik 3, 127, str. 38-41. Zagreb.

\section{SAŽETAK}

U ovom radu dat je pregled do sada najčešće korištenih i razvijanih tehnika i tehnologija, koje se koriste u lovnom gospodarenju. Za hvatanje divljači, koristile su se a i danas, razne vrste klopki, zamki, hvataljki i mreža za hvatanje. Uz hvatanja sitne divljači (zečeva i poljskih jarebica), najznačajnija hvatanja mrežama, vršena su u drugoj polovini prošlog vijeka (1964-1988) u Bosni i Hercegovini, kada je u posebnom lovištu Prenj, uhvaćeno i isporučeno ukupno 434 grla divokoza u Srbiju, Hrvatsku, Argentinu i Novi Zeland, kao i na 10 lokaliteta u BiH.

Po izvršenom hvatanju, posebno krupne divljači, vrši se i hemijska imobilizacija koja se provodi davanjem sredstva za uspavljivanje (ili samo smirenje), što se može dati pomoću puške ili puhalice za uspavljivanje. Na ovaj način se osigurava provođenje predviđenog tretmana ili transporta divljači bez štetnih posljedica po samu divljač ili operatere.

Senzorne kamere se koriste za utvrđivanje brojnosti divljači, polne i starosne strukture, kao i za identifikaciju prisustva rijetkih i pojave novih vrsta divljači. Takođe se koriste za utvrđivanje predatorskih vrsta u staništima velikog tetrijeba, kao i za nadzor lovišta. Ključni element senzornih kamera je - senzor. Testiranjem upravo ovog segmenta došlo se do podatka da je optimalna udaljenost "objekta" 10 - 15 metara (iznimno do 20 metara). Ovo je zapravo "slaba tačka" ovih uređaja. Donekle se ovaj nedostatak može ublažiti da se kamera programira na način da u zadanim vremenskim intervalima načini fotografiju prostora ispred sebe bez obzira da li se nalazi divljač u tom prostoru ili ne. Telemetrijsko praćenje divljači provodi se već više od 30 godina. Od primjene klasičnih ogrlica s odašiljačem, antenom i prijemnikom do danas kada se koriste GPS ogrlice i satelitsko praćenje jedinki. Ove tehnike primjenjuju se na sve vrste divljači od manjih (poljska jarebica) do najvećih (medvjedi). 
Mjerenje elemenata mikroklime preciznim instrumentima (mobilna meteorološka stanica), koja bilježi sve klimatske parametre, izvodi se posebno u staništima koja su teško pristupačna i relativno udaljena od zvaničnih meteoroloških stanica, kako bi se na što precizniji način utvrdili uslovi koji vladaju u datom staništu, a od neminovnog su uticaja na vrstu divljači koju istražujemo.

Testiranje senzornih zvučnih rastjerivača divljači za sprečavanje šteta od divljači provedeno je na više lokacija a usmjerenih prvenstveno na divlje svinje i jelensku divljač. Konstatovana je zadovoljavajuća efikasnost ovih uređaja kod sprečavanja izlaska divljači na puteve u svrhu sprečavanja šteta u saobraćaju, ali efekat ovih uređaja nije zadovoljavajući kada se radi o sprečavanju šteta u poljoprivredi.

Provedena istraživanja primjene bespilotnih letjelica kretala su se u dva smjera:

- Analiza staništa

- Prebrojavanje divljači

Prva primjena odnosi se na snimanje realnog stanja strukture površina unutar lovišta $u$ svrhu što točnije procjene lovnogospodarskog kapaciteta staništa za pojedinu vrstu divljači. Za tu svrhu koristi se kamera visoke rezolucije i snimanje se vrši na način da se teren skenira uzastopnim fotografijama određenog preklopa. Obzirom je većina letjelica opremljena GPS-om svaka snimljena fotografija smještena je u prostor tako da se postupnim skeniranjem površina i potom korištenjem namjenskih programa po potrebi može dobiti slika odnosno 3D model cijelog lovišta. Bespilotnim letjelicama takođe je vršeno prebrojavanje krupne divljači unutar šumskih predjela poznate površine gdje se očekivala povećana koncentracija divljači (branjevine) koristeći različite metode: apsolutnog prebrojavanja svih jedinki neke vrste na plohi poznate površine ili metoda transekta, gdje se na unaprijed određenim pravcima poznate površine prebrojava divljač, pogodna je za veće površine i predstavlja metodu uzorka. $\mathrm{Na}$ bespilotnim letjelicama se u ovu svrhu postavljala i termovizijska kamera.

Na kraju, možemo zaključiti da razvoj tehnike i tehnologije u lovnom gospodarenju umnogome povećava naša saaznanja o samoj divljači, te istovremeno olakšava brojne radnje koje se provode u lovnoj praksi.

Corresponding author: Marijan Grubešić, Faculty of Forestry University of Zagreb; Svetošimunska 25, 10000 Zagreb, Croatia; e-mail address: grubesic@sumfak.hr 